\title{
International Reserves-Too Much \\ of a Zipf's Thing
}

Mariusz Sumlinski 



\title{
IMF Working Paper
}

\author{
Middle East and Central Asia Department \\ International Reserves-Too Much of a Zipf's Thing \\ Prepared by Mariusz Sumlinski ${ }^{1}$
}

Authorized for distribution by Edward Gardner

January 2008

\begin{abstract}
This Working Paper should not be reported as representing the views of the IMF. The views expressed in this Working Paper are those of the author(s) and do not necessarily represent those of the IMF or IMF policy. Working Papers describe research in progress by the author(s) and are published to elicit comments and to further debate.
\end{abstract}

Concentrated distribution of international reserves is puzzling. I show that the growth rates of international reserves bear only a very weak relationship to their initial stocks (scaled by GDP or in absolute terms), and that, by implication, the cross-sectional distribution of reserves conforms to Zipf's law. The law states that the size of reserves is inversely related to their ranking. Evidence in favor of the law is strong and time robust. I compare the crosssection distribution of international reserves embedded in the WEO projections to that implied by Zipf's law and find that international reserves are much less concentrated in the WEO projections than implied by Zipf's law.

JEL Classification Numbers:F30, F31, F33

Keywords: Gibrat's law, Zipf’s law, international reserves

Author’s E-Mail Address:msumlinski@imf.org

\footnotetext{
${ }^{1}$ The author wishes to thank Edward Gardner whose comments added clarity and strength to the paper's argument.
} 


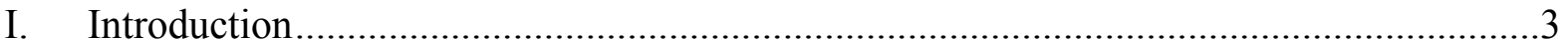

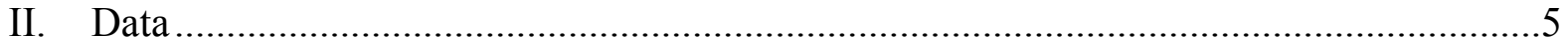

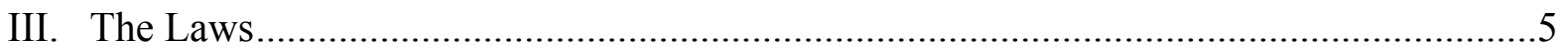

IV. Reserves Size and Rank: Gibrat's Law...............................................................6

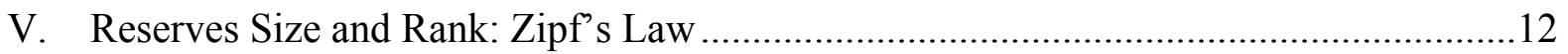

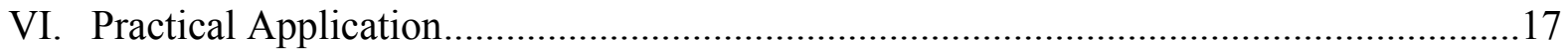

VII. Conclusion …..................................................................................................... 18

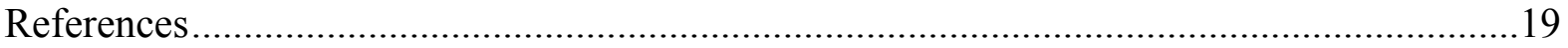

Tables

1. Descriptive Statistics for International Reserves .....................................................5

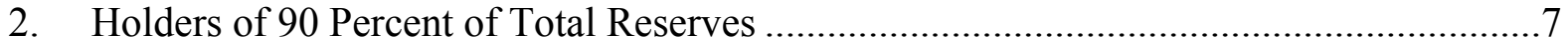

3. Gibrat Coefficients for Reserve Holdings (Scaled by GDP) ....................................

4. Gibrat Coefficients for Reserve Holdings (Absolute Sizes) .........................................9

5. Zipf Coefficients for Reserve Holdings ................................................................... 12

Figures

1. Gibrat's Law for Reserves-Full Sample Average Growth Rate on

Log Initial Size-Initial Year/Final Year

2. Gibrat's Law for 90 Percent of Reserves Average Growth Rate on Log Initial Size - Initial Year/Final Year ................................................................ 11

3. Zipf's Law for Reserves -Full Sample Log Rank on Log Size, 1948-71 ...................13

4. Zipf's Law for Reserves_-Full Sample Log Rank on Log Size, 1980-2006 .................14

5. Zipf's Law for 90 Percent of Reserves_-Log Rank on Log Size, 1948-71 ..................15

6. Zipf's Law for 90 Percent of Reserves_-Log Rank on Log Size, 1980-2006 ...............16

7. Zipf's Law for 90 Percent of WEO Projected Reserves-Log Rank on Log Size, 2008-12 


\section{INTRODUCTION}

Lawrence H. Summers: with respect to the use of reserves in crisis prevention, that is, reducing the probability of a crisis, it is hard to demonstrate conclusively that there are any statistically significant benefits at all (Jeanne, 2007).

General Discussion: Richard Cooper reminded the panel [...] that he had never met an official who thought in terms of optimal reserves; it should not be surprising, then, that reserves accumulation in many developing economies is not in accord with the normative prescriptions of [...] [the] model (Jeanne, 2007).

The recent large accumulation of reserves, especially by developing countries, has sparked much research into the motivation underlying such accumulation including its relationship to optimal reserve holding theories. In recent years, reserves have grown rapidly with a substantial share of this growth taking place in developing economies - most notably in a very rapidly growing China. Excess accumulation of reserves relative to established norms is often viewed as evidence of "mercantilist" policies. Most of the reserve assets are issued by the United States - the largest world economy. As the dollar has been depreciating against a background of a deep-rooted saving-investment imbalance, the concentration of reserves compounds concerns about the possibility that large reserve holders might dump these assets rapidly in the market.

Much of the empirical literature has focused on the extent to which reserve accumulation conforms to an optimizing behavior. In as much as reserves serve as insurance against adverse balance of payments pressures and shocks (and as a means to strengthen market confidence), ${ }^{2}$ their accumulation should respond to objective criteria as measured by adequacy and optimality benchmarks. Adequacy is typically judged using various rules of thumb ${ }^{3}$ and optimality using varied modeling approaches. ${ }^{4}$ However, international reserve levels often diverge (in both directions) from desired standard.

If reserve accumulation and holding patterns were guided by an optimal reserve objective, one should observe an inverse correlation between the initial size of reserve (relative to its optimal level) and the growth rate of reserves. ${ }^{5}$ I test this proposition by looking at the

\footnotetext{
${ }^{2}$ These might include: assuring smooth functioning of international transactions, intervention in the foreign exchange market to counter market pressures, providing liquidity assurances to banks and depositors in dollarized economies, signaling a commitment to cover international obligations without interruption.

${ }^{3}$ Ratios to short term debt, imports, GDP, and broad money are used most frequently.

${ }^{4}$ For example, buffer stock models (Goetlieb, 1985) cost-benefit analysis (Jeanne, 2007), modeling relations to monetary aggregates (Obstfeld and others, 2007), etc.

5 "Lawrence H. Summers: Soon after I arrived at the Treasury [...] in 1993, I was briefed about the Exchange Stabilization Fund. [...] I asked [...] why this fund, [...] was the size it was. I received two answers. One came from the Treasury staff and consisted of a lengthy disquisition on the series of historical events leading from the fund's beginnings to date. The other came from [...] Alan Greenspan, who explained [...] that depending upon certain assumptions that were difficult to pin down, the optimal level was somewhere between $\$ 20$ billion and \$2 trillion." (Jeanne, 2007)
} 
relationship between the level of reserves (scaled by GDP) and their growth rates and find that the evidence for that is weak. This phenomenon, a lack of correlation between a variable's initial stock and its growth rate, is a well-established empirical regularity called Gibrat's law — after Gibrat — who was the first to document it at the beginning of the last century in relation to the firms' growth process. Admittedly, the optimal level of reserve cannot be reduced to its ratio to GDP as it will depend on a host of other factors such as short-term external debt, money, current account balance or imports, exposure to terms of trade shocks, etc. Nonetheless, given the strong correlation of GDP to most of these other variables, lack of statistically significant correlations between the growth rate of reserves and the reserve to GDP ratio constitutes an empirical puzzle. I also test for Gibrat's law using absolute level of reserves (not scaled by GDP) and find that evidence for its presence is not as significant.

Growth processes that follow the Gibrat's law give rise to a regularity called Zipf's Law (Gabaix, 1999). A variable follows Zipf's law if its size realizations $\left(S_{i}\right)$ are inversely related to their ranking $\left(R_{i}\right)$ with a slope of one $(\alpha=1)$ as in equation (1) below.

$$
\ln \left(R_{i}\right)=\ln (A)-\alpha \ln \left(S_{i}\right)
$$
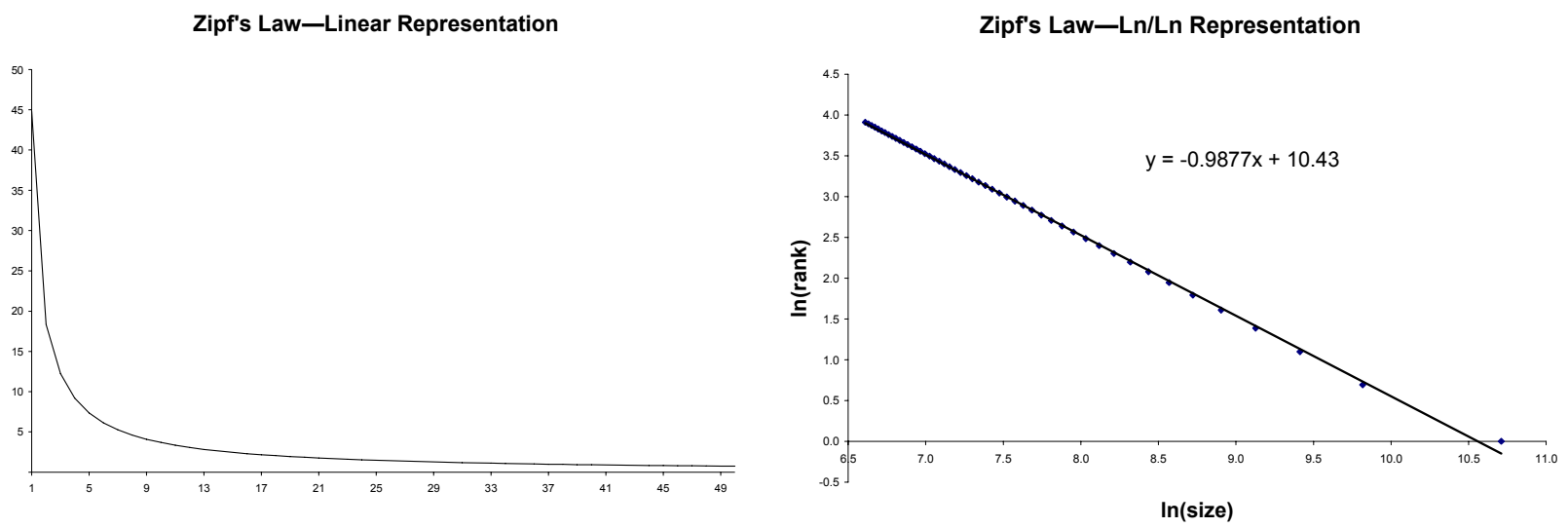

This regularity has been observed with respect to frequency of usage of words (Zipf, 1949), firms' sizes (Simon, 1955; and Axtell, 2001), city sizes (Krugman, 1996 among others), country sizes (ranked by population) (Rose, 2005), and as I show in this paper international reserve sizes.

In practical terms, in as much as this empirical finding does not support the view of a convergence of reserves to their optimal level, it also lends support to the continued value of reserve management funds and collective insurance arrangements (such as IMF) that would spread perceived benefits from high reserve holdings by a few to a larger number of countries. Also, as the evidence of Zipf's law is robust over time, it can be viewed as a useful predictor of the distribution of projected international reserves going forward, for instance the one embedded in the WEO projections. 
This short paper proceeds as follows-I describe the data in Section II, Section III introduces Gibrat's and Zipf's law. In Sections IV and V, I establish their empirical relevance to international reserves. Section VI suggests a practical application for my findings and Section VII concludes.

\section{DATA}

Table 1 includes descriptive statistics of the data - international reserve excluding goldused in this paper. The data are sourced from the IMF International Financial Statistics (IFS).

Table 1. Descriptive Statistics for International Reserves

\begin{tabular}{lrrrrrrrr}
\hline & 1948 & 1950 & 1960 & 1971 & 1980 & 1990 & 1997 & 2006 \\
\hline & & & \multicolumn{7}{c}{ (In millions of U.S. dollars) } & & & \\
Mean & 215 & 206 & 254 & 826 & 2,976 & 5,717 & 9,076 & 28,015 \\
Standard error & 53 & 42 & 57 & 204 & 573 & 1,119 & 1,806 & 8,164 \\
Median & 73 & 76 & 91 & 91 & 334 & 353 & 682 & 2,367 \\
Standard deviation & 448 & 356 & 523 & 2,173 & 6,611 & 13,566 & 24,030 & 108,921 \\
Minimum & 0 & 0 & 1 & 0 & 1 & 1 & 0 & 15 \\
Maximum & 3,099 & 1,810 & 4,062 & 14,622 & 48,592 & 78,501 & 219,648 & $1,068,493$ \\
Sum & 15,234 & 14,829 & 21,615 & 93,380 & 395,760 & 840,416 & $1,606,375$ & $4,986,624$ \\
Count & 71 & 72 & 85 & 113 & 133 & 147 & 177 & 178 \\
\hline
\end{tabular}

Source: International Financial Statistics (Washington: IMF).

As we can see from Table 1 growth of reserves has been staggering. The mean reserve holdings increased 131 times since 1948 and almost 5 times since 1990. The maximum value went up during the same period by 355 times, 14 times since 1990. The coverage has also expanded - from 71 countries reporting to the IMF in 1948, to 147 in 1990, to 178 in 2006.

\section{THE LAWS}

Gibrat's law is named after Robert Gibrat who in 1931 when modeling the dynamics of firm size and industry structure noted the presence of this regularity. ${ }^{6}$ Gibrat's law says, in our case, that the expected growth rate of reserves is independent of the initial size of reserves. ${ }^{7}$

Zipf's law is named after a Harvard linguist, George Kingsley Zipf who formulated it in the course of his study of languages (Zipf, 1949). In reference to cities, firms, or countries the law says that the number of occurrences of a certain variable greater than $S$ is approximately proportional to $1 / S$. This formulation assumes an exponent of -1 on $S$. More general formulation relates a rank to $S^{-\alpha}$ (see equation (1) above).

Gabaix (1999) shows that there is a strong link between Gibrat's law and Zipf's law. If growth process conforms to Gibrat's law then a variable will be distributed according to Zipf's law. It has also been noted, with respect to cities and country studies, that when the

\footnotetext{
${ }^{6}$ See Sutton (1997) for an extensive discussion of the law's application to a manufacturing industry.

${ }^{7}$ See e.g., Delgado and Godinho (2004) for its application to city sizes and Rose (2007) for application in reference to country sizes.
} 
largest possible sample (in effect a population) is included in the analysis the laws hold only weakly, but the evidence for the laws' presence is convincing for samples limited to the largest subjects - accounting for majority of population. In the case of U.S. cities, studies focused on 50 largest metropolitan areas. To control for this peculiarity I estimate the law for sub-samples corresponding to 75,90 , and 100 percent coverage of total reserves. ${ }^{8}$ Countries accounting for up to 90 percent of reserve holdings and their respective shares are listed, in descending order, in Table 2.

\section{RESERVES Size AND RANK: GibRAT's LAW}

As noted above, reserves serve important macroeconomic purposes. Therefore it is reasonable to expect that their growth would be influenced by their initial size normalized by some scaling variable for example GDP - low stocks would need to be brought up and the excessive ones would need to be brought down. To see if such relationship holds I relate reserves growth to their size scaled by GDP and to their absolute size, as well. I split the data between Bretton Woods period and post-Bretton Woods period and relate growth of reserves to the following initial points - 1948 (1960 for reserves scaled by GDP owing to GDP data limitations) - the first year of data in the IFS database, 1971 - the year of collapse of Bretton Woods, 1997-the year of Asian crisis, and 1971 again for the whole (till 2006) post-Bretton Woods period. Testing for this relationship is equivalent to testing for a presence of Gibrat's law.

Table 3 includes results of the estimation using reserves scaled by GDP as an independent variable. The results show that the evidence for existence of a relationship between an initial size of reserves and their subsequent growth (i.e., against Gibrat's law) is weak. For the population of countries, t-statistics approach conventional levels of significance, indicating that Gibrat's law might not hold, only for the period 1960-71 and 1997-2006 - in other words the growth rate of reserves does depend on their initial period sizes, scaled by GDP. This might be the case for two reasons. One, there exists a relationship between reserves growth and their initial stock as suggested by the theory or, two the seeming relationship might have to do with the peculiarities of the data - the lower tail of the population is not diversified enough. ${ }^{9}$ To control for that I re-run the regressions for sub-samples accounting for 75 and 90 percent of the total world stock of reserves. For these sub-samples I can conclude that Gibrat's law holds - the slopes are not significantly different from zero. ${ }^{10}$ All of the equations fit the data poorly.

\footnotetext{
${ }^{8}$ I use IMF IFS data for international reserves excluding gold for 1948-2006.

${ }^{9}$ This is also observed in analysis of cities and countries (ranked by population) Rose (2005).

${ }^{10}$ As the slopes are not significantly different than zero there is insufficient evidence to accept the hypothesis posed above about a negative relationship between the initial size of reserves and their subsequent growth.
} 


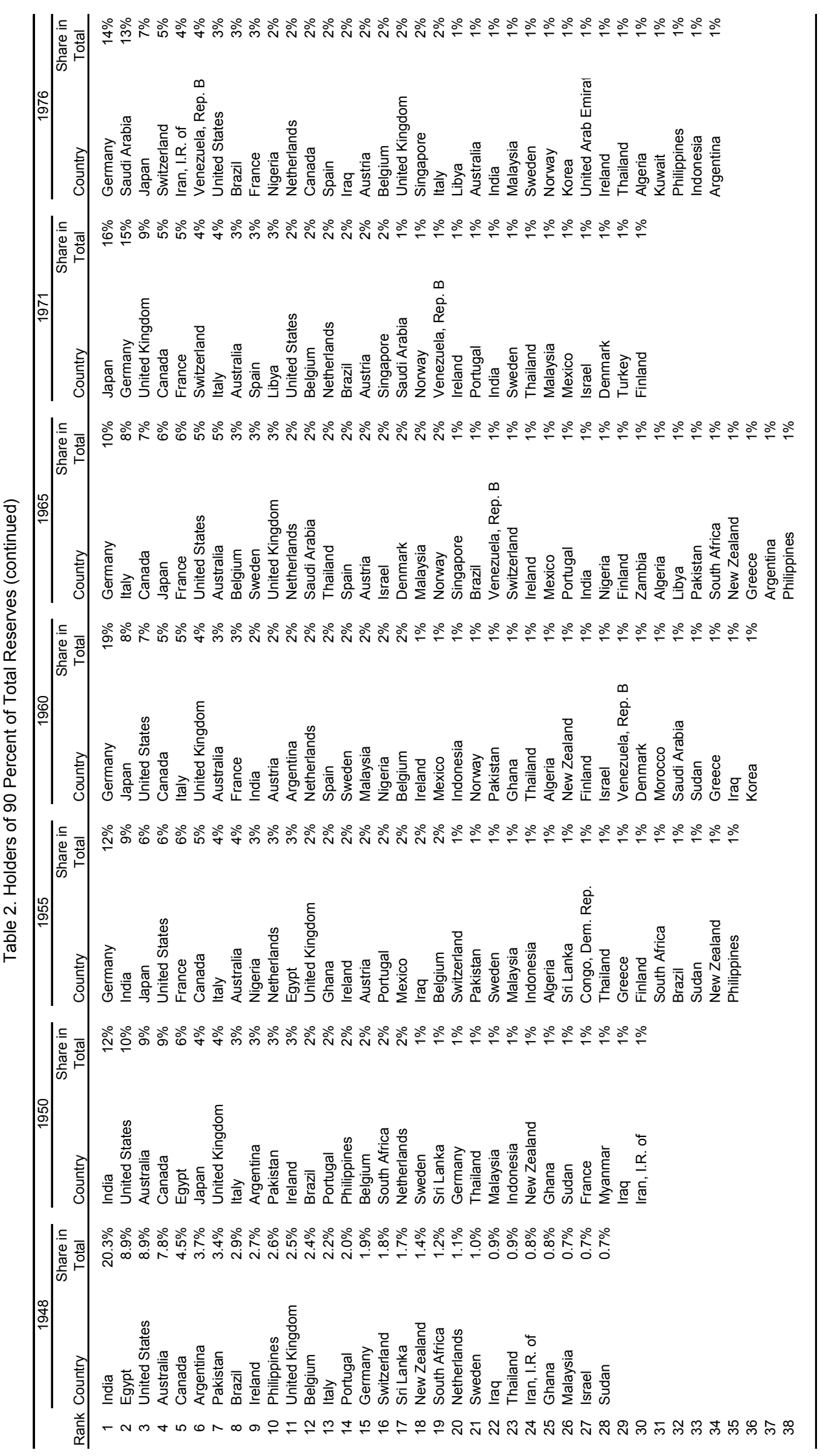




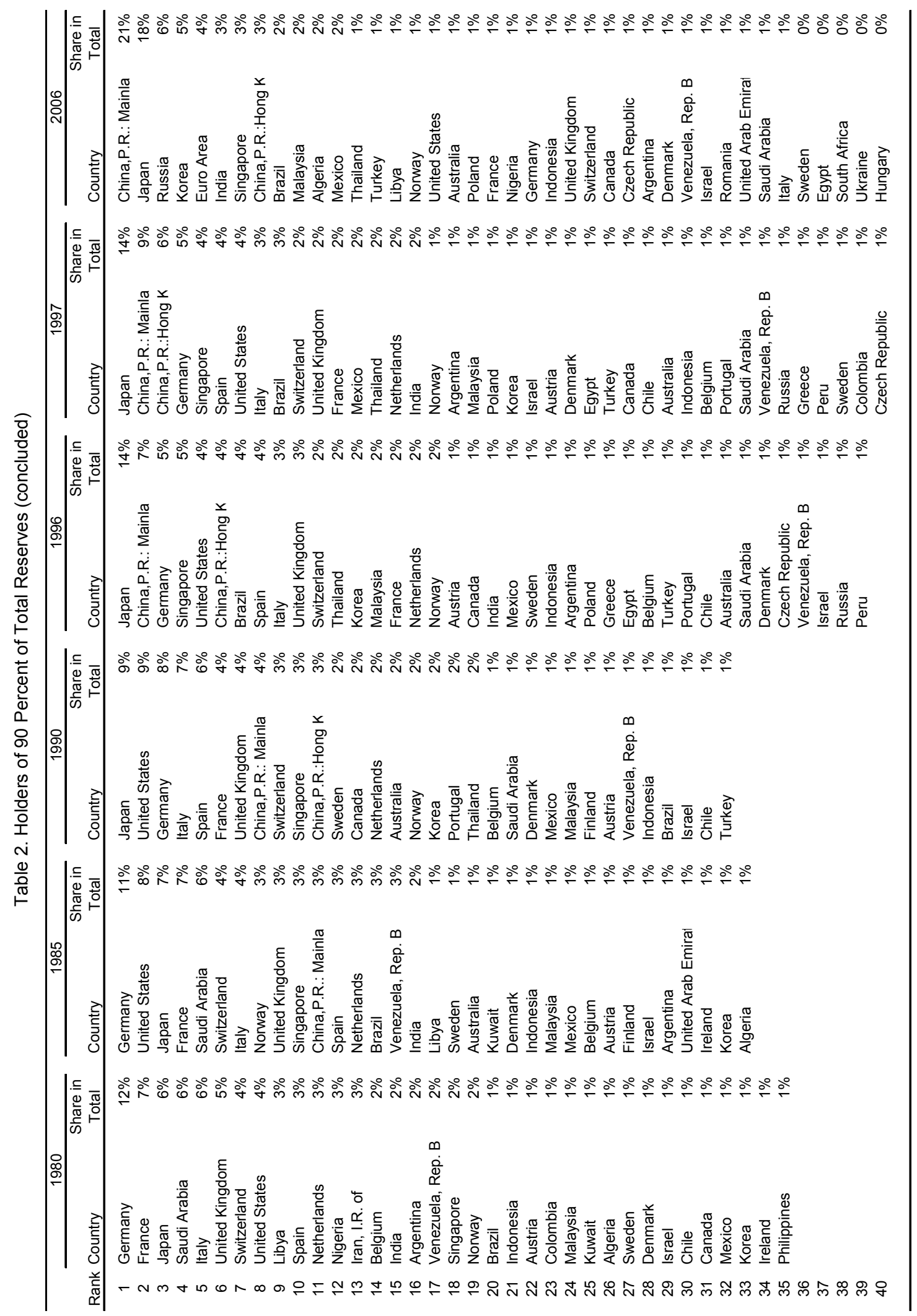


Table 3. Gibrat Coefficients for Reserve Holdings (Scaled by GDP)

\begin{tabular}{|c|c|c|c|c|c|c|}
\hline Dep./Indep. & Percent of Total Reserves & Sample & Slope & T-Statisti & & $\mathrm{R}^{2}$ \\
\hline Avg. growth rate 61-71/Reserves/GDP'60 1/ & 100 & 67 & -0.9 & -2.3 & *** & 0.1 \\
\hline \multirow[t]{3}{*}{ Avg. growth rate $72-96 /$ Reserves/GDP'71 } & 75 & 13 & -0.6 & -1.2 & & 0.1 \\
\hline & 90 & 27 & 0.0 & -0.5 & & 0.0 \\
\hline & 100 & 96 & -0.5 & -0.5 & & 0.0 \\
\hline \multirow[t]{3}{*}{ Avg. growth rate 98-06/Reserves/GDP'97 } & 75 & 23 & 0.0 & 0.1 & & 0.0 \\
\hline & 90 & 40 & -0.1 & -0.4 & & 0.0 \\
\hline & 100 & 160 & -1.3 & -2.3 & *** & 0.0 \\
\hline \multirow[t]{3}{*}{ Avg. growth rate $72-06 /$ Reserves/GDP'71 } & 75 & 13 & -0.4 & -0.9 & & 0.1 \\
\hline & 90 & 27 & 0.0 & -0.5 & & 0.0 \\
\hline & 100 & 91 & -0.6 & -0.7 & & 0.0 \\
\hline
\end{tabular}

1/ Only a regression for the full sample is run. Data for GDP are not available for Germany-a holder of the largest share (16 percent) of reserves.

Without Germany, the remaining observations account for 100 percent of usable data for all sample selections.

*** significant at 5 percent.

Next, I repeat the test of Gibrat's law for absolute sizes of reserves (not scaled by GDP). For this set of regression I am able to start with 1948 as the first year of observations since the data set for reserves goes back all the way to 1948. The results are summarized in Table 4. Overall, the results are mixed but tilted more against Gibrat's law than the results for reserves scaled by GDP. For the population, t-statistics indicate that Gibrat's law does not hold for all the periods tested - in other words the growth rate of reserves does depend on their sizes in the initial period, as one would expect given use theories of international reserves. Here again I re-run the regressions for sub-samples accounting for 75 and 90 percent of the total world stock of reserves. For these sub-samples I can again conclude that the evidence for Gibrat's law is mixed. The slopes are not significantly different from zero for 1997-2006 but for other periods some of the results approach conventional (although low) significance levels. All of the equations fit the data $(75,90$, and 100 percent) poorly (Table 4$)$.

Table 4. Gibrat Coefficients for Reserve Holdings (Absolute Sizes)

\begin{tabular}{|c|c|c|c|c|c|c|}
\hline Dep./Indep. & Percent of Total Reserves & Sample & Slope & T-Statistic & & $\mathrm{R}^{2}$ \\
\hline \multirow[t]{3}{*}{ Avg. growth rate $49-71 / \ln ($ Reserves'48) } & 75 & 14 & -0.1 & -1.7 & ** & 0.2 \\
\hline & 90 & 27 & 0.0 & -0.4 & & 0.0 \\
\hline & 100 & 69 & -0.1 & -4.8 & *** & 0.3 \\
\hline \multirow[t]{3}{*}{ Avg. growth rate $72-96 / \ln ($ Reserves'71) } & 75 & 13 & 0.0 & -0.9 & & 0.1 \\
\hline & 90 & 27 & 0.0 & -2.1 & *** & 0.1 \\
\hline & 100 & 106 & -0.1 & -1.7 & ** & 0.0 \\
\hline \multirow[t]{3}{*}{ Avg. growth rate $98-06 / \ln \left(\right.$ Reserves$\left.^{\prime} 97\right)$} & 75 & 23 & 0.0 & -0.2 & & 0.0 \\
\hline & 90 & 40 & 0.0 & -0.4 & & 0.0 \\
\hline & 100 & 170 & -0.1 & -5.2 & *** & 0.1 \\
\hline \multirow[t]{3}{*}{ Avg. growth rate $72-06 / \ln ($ Reserves'71) } & 75 & 13 & 0.0 & -0.2 & & 0.0 \\
\hline & 90 & 27 & 0.0 & -1.9 & ** & 0.1 \\
\hline & 100 & 100 & -0.1 & -2.2 & *** & 0.0 \\
\hline
\end{tabular}

*** significant at 5 percent; ** significant at 10 percent

Graphical evidence for influence of Gibrat's law on international reserves formation is presented in Figures 1 and 2. Figure 1 includes charts for the full sample and Figure 2 for a sample covering 90 percent of the total reserve holdings. 
Figure 1. Gibrat's Law for Reserves-Full Sample

Average Growth Rate on Log Initial Size_Initial Year/Final Year
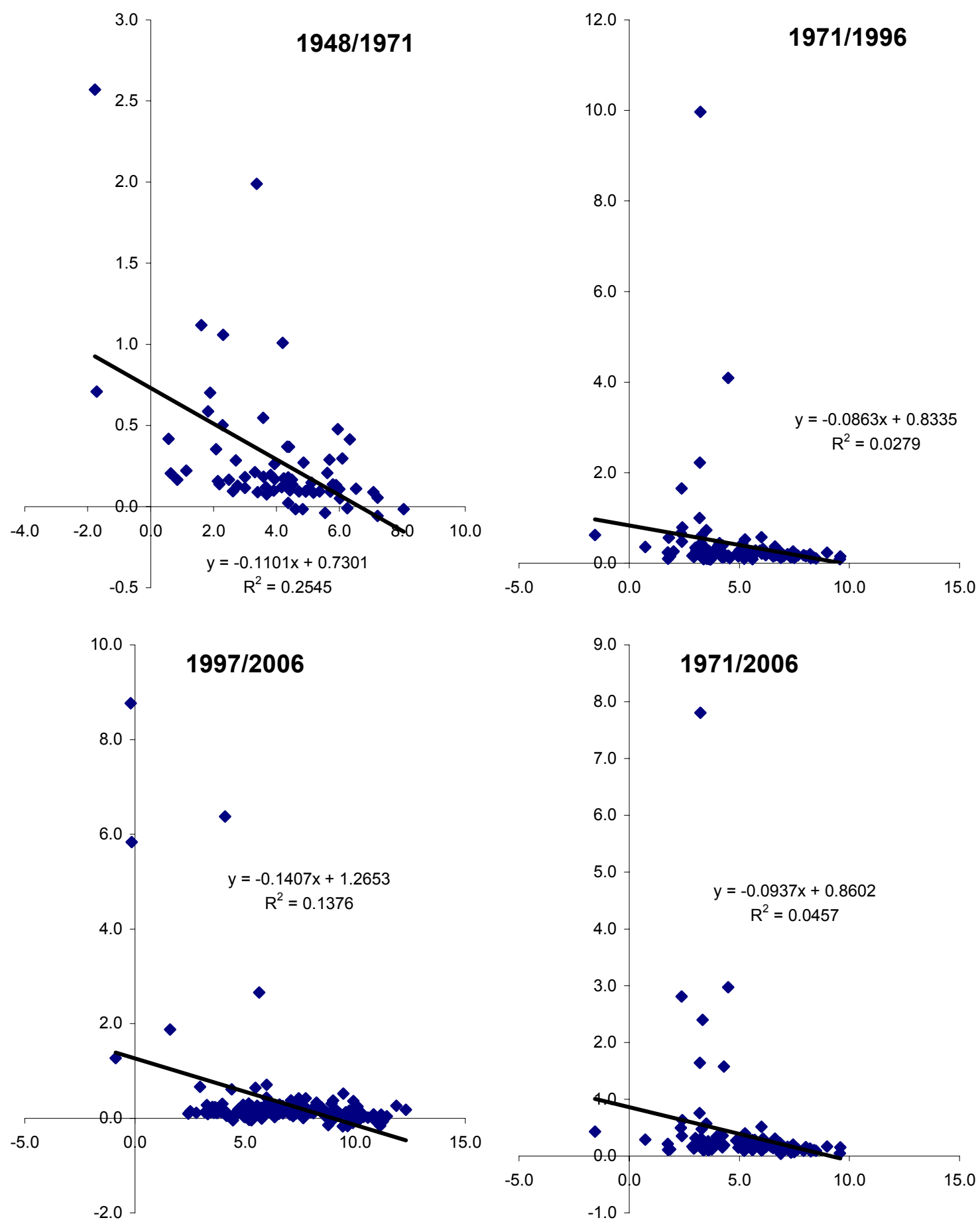

Source: Author's calculations using IMF IFS data on total reserves minus gold. 
Figure 2. Gibrat's Law for 90 Percent of Reserves

Average Growth Rate on Log Initial Size_Initial Year/Final Year
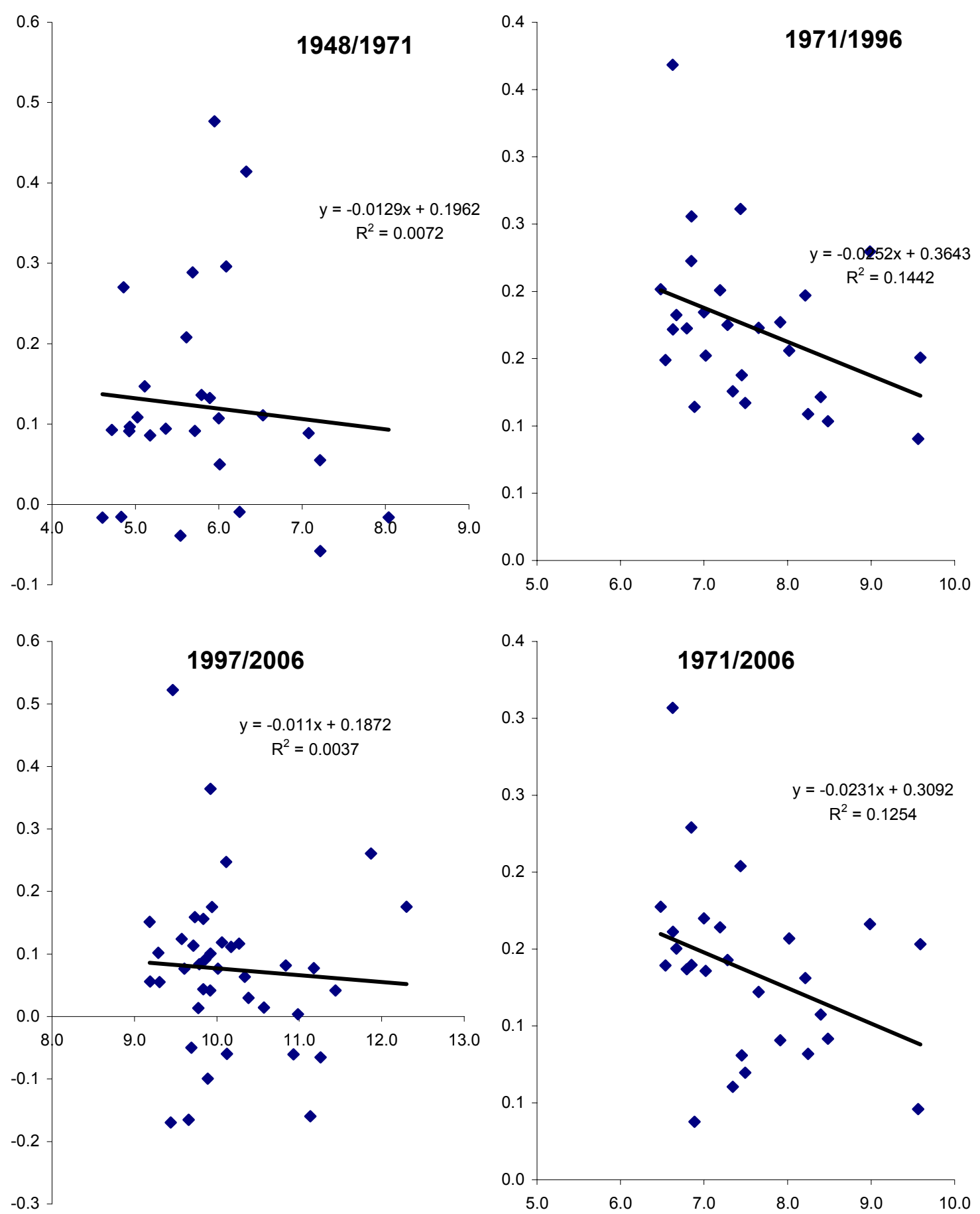

Source: Author;s calculations using IMF IFS data on total reserves minus gold. 


\section{RESERVES SIZE AND RANK: ZIPF'S LAW}

I established that Gibrat's law should to some extent affect the process of reserve formation. As mentioned above, Gibrat's law influence on the process of formation of international reserves should result in the latter being distributed according to the Zipf's law. The evidence for presence of Zipf's law is presented in Table 5 and in Figures 3-6. The results for the IFS population are presented in Figures 3 and 4 and for a sample corresponding to 90 percent of the total in Figures 5 and 6. The Bretton Woods period is described in Figure 3 (full sample) and Figure 5 (90 percent). Post-Bretton Woods period in Figure 4 (full sample) and Figure 6 (90 percent).

\begin{tabular}{|c|c|c|c|c|c|}
\hline Year & Percent of Total Reserves & Sample & Slope & T-Statistics & $\mathrm{R}^{2}$ \\
\hline \multirow[t]{3}{*}{1948} & 75 & 14 & -1.1 & -16.4 & 1.0 \\
\hline & 90 & 28 & -0.9 & -27.0 & 1.0 \\
\hline & 100 & 70 & -0.4 & -13.7 & 0.7 \\
\hline \multirow[t]{3}{*}{1950} & 75 & 16 & -1.2 & -13.8 & 0.9 \\
\hline & 90 & 30 & -1.0 & -25.6 & 1.0 \\
\hline & 100 & 71 & -0.4 & -14.1 & 0.7 \\
\hline \multirow[t]{3}{*}{1960} & 75 & 20 & -1.1 & -27.6 & 1.0 \\
\hline & 90 & 36 & -1.1 & -44.2 & 1.0 \\
\hline & 100 & 85 & -0.5 & -18.1 & 0.8 \\
\hline \multirow{3}{*}{1971} & 75 & 14 & -1.1 & -17.3 & 1.0 \\
\hline & 90 & 30 & -0.9 & -35.1 & 1.0 \\
\hline & 100 & 113 & -0.4 & -25.7 & 0.9 \\
\hline \multirow[t]{3}{*}{1980} & 75 & 19 & -1.3 & -15.4 & 0.9 \\
\hline & 90 & 35 & -1.1 & -23.8 & 0.9 \\
\hline & 100 & 132 & -0.3 & -22.9 & 0.8 \\
\hline \multirow[t]{3}{*}{1990} & 75 & 18 & -1.3 & -12.4 & 0.9 \\
\hline & 90 & 32 & -1.1 & -20.3 & 0.9 \\
\hline & 100 & 146 & -0.3 & -26.4 & 0.8 \\
\hline \multirow[t]{3}{*}{1997} & 75 & 24 & -1.2 & -33.1 & 1.0 \\
\hline & 90 & 40 & -1.2 & -43.8 & 1.0 \\
\hline & 100 & 177 & -0.3 & -26.3 & 0.8 \\
\hline \multirow[t]{3}{*}{2006} & 75 & 17 & -0.9 & -24.0 & 1.0 \\
\hline & 90 & 40 & -0.9 & -55.2 & 1.0 \\
\hline & 100 & 176 & -0.4 & -30.7 & 0.8 \\
\hline
\end{tabular}

For the population the results indicate that reserve holdings are not distributed according to Zipf's law. This is illustrated in Table 5 and Figures 3 and 4. The slope is less than one for all (Bretton Woods and post-Bretton Woods) years, statistically significant, and the regression fit is very good. Next, I want to find out if Zipf's law holds for a sample smaller than population, and at what percentage of total reserves the law holds. To establish that, for the years selected, I run regressions starting at 12 observations (corresponding to about 60 percent of the total) and next, extend coverage all the way to the full sample. I find that distribution of reserves for a sample of countries accounting for a share of total reserves as high as 90 percent is fairly well approximated by Zipf's distribution. Formally this seems in accordance with what is observed in investigations of Zipf's law in relation to cities and countries (ranked by population). The population is not differentiated enough at its lower tail-it includes too many members with approximately the same size of reserves. But, the results for 90 percent of the total are as expected - all slopes are very close to 1, very strongly significant, and the fit of regressions is very good (Table 5). 
Figure 3. Zipf's Law for Reserves-Full Sample Log Rank on Log Size, 1948-71
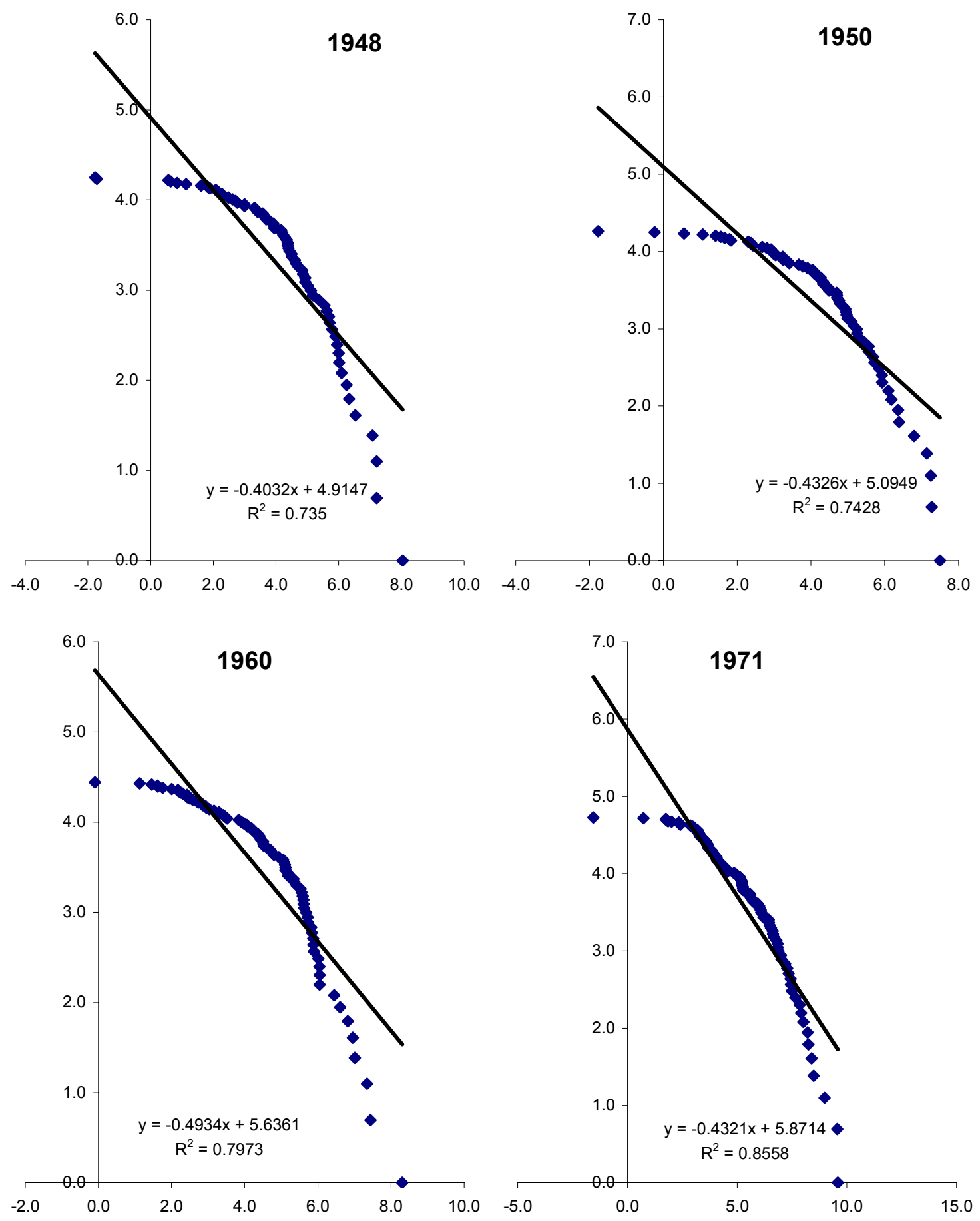

Source: Author's calculations using IMF IFS data on total reserves minus gold. 
Figure 4. Zipf's Law for Reserves—Full Sample Log Rank on Log Size, 1980-2006
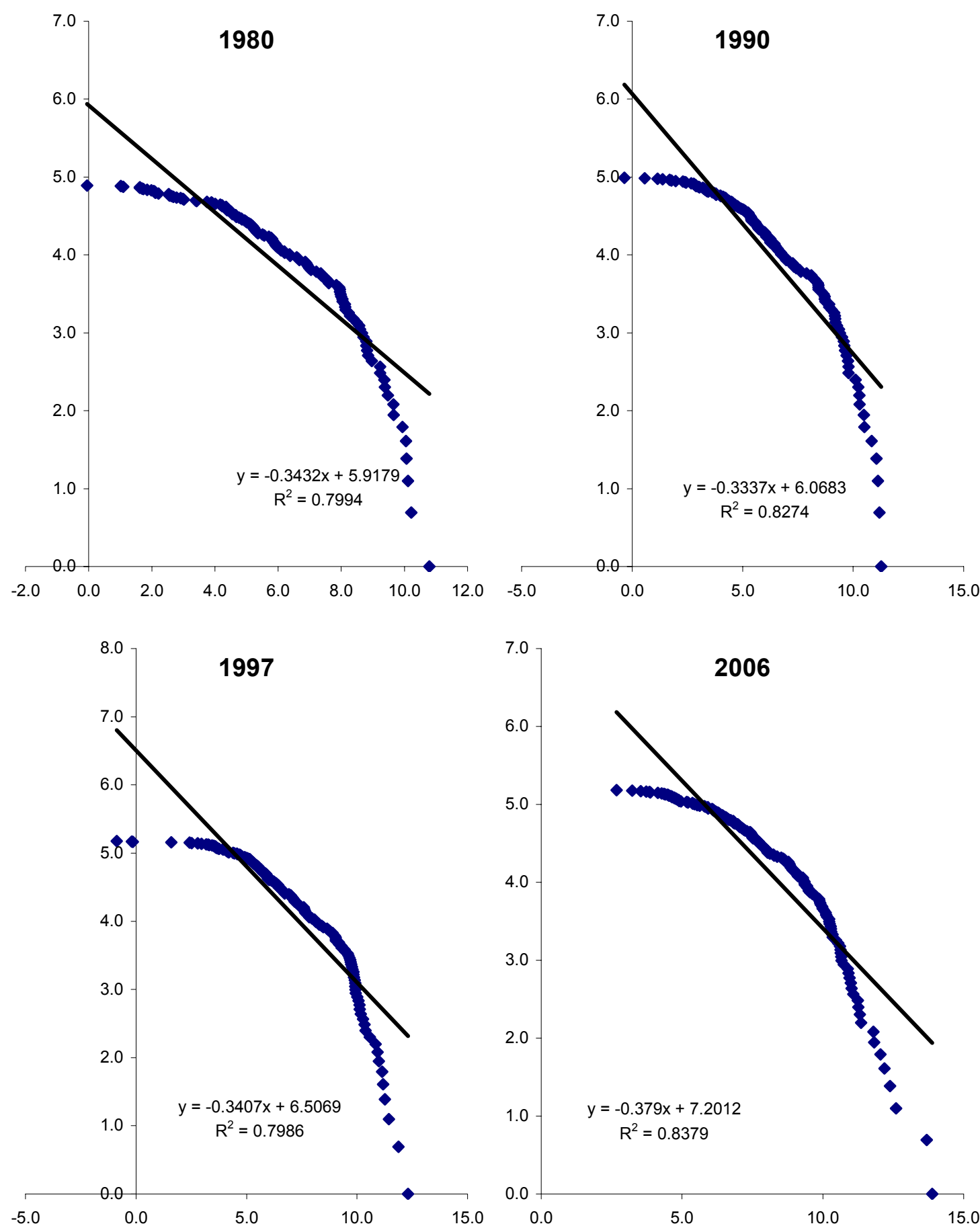

Source: Author's calculations using IMF IFS data on total reserves minus gold. 
Figure 5. Zipf's Law for 90 Percent of Reserves_Log Rank on Log Size, 1948-71
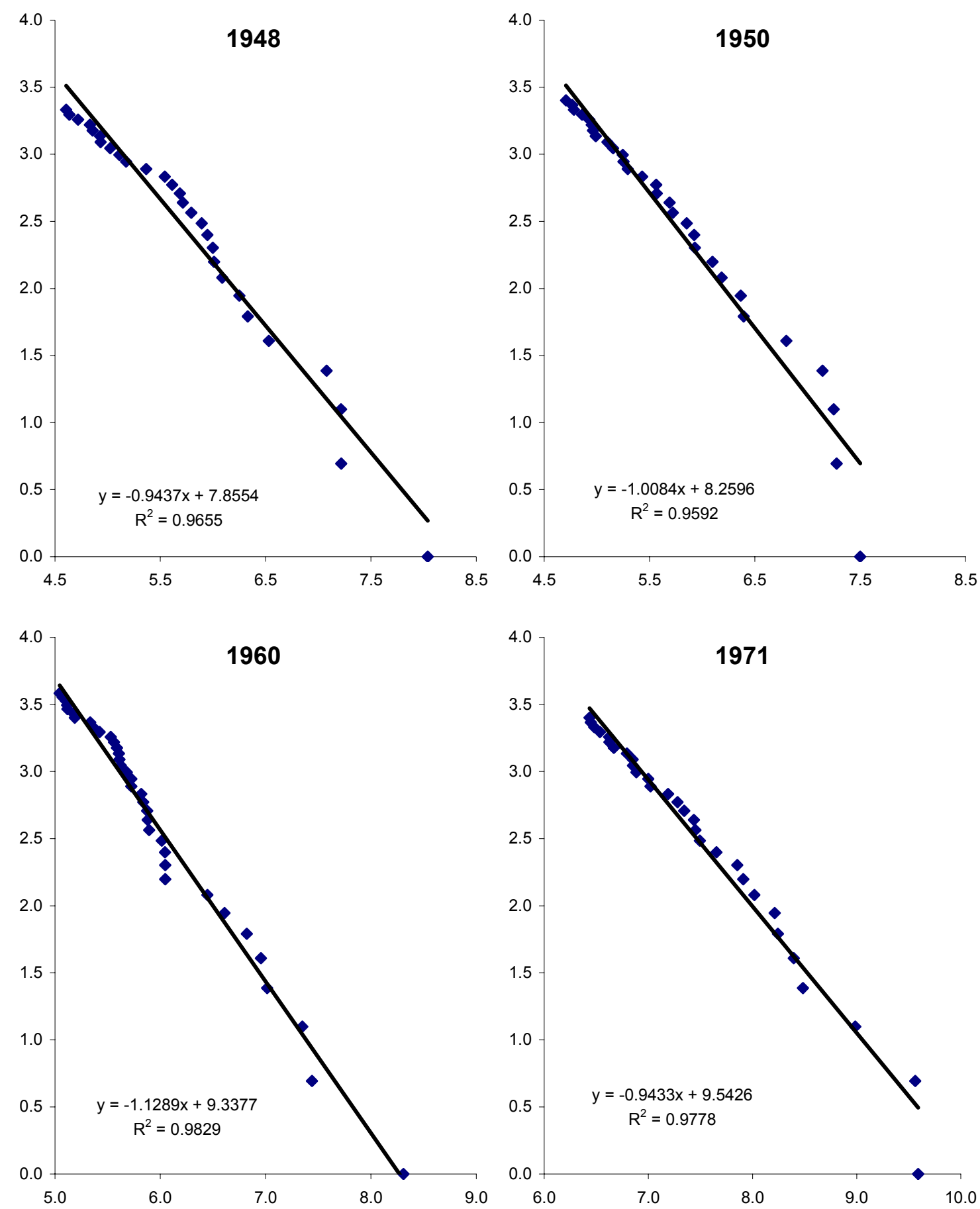

Source: Author's calculations using IMF IFS data on total reserves minus gold. 
Figure 6. Zipf's Law for 90 Percent of Reserves—Log Rank on Log Size, 1980-2006
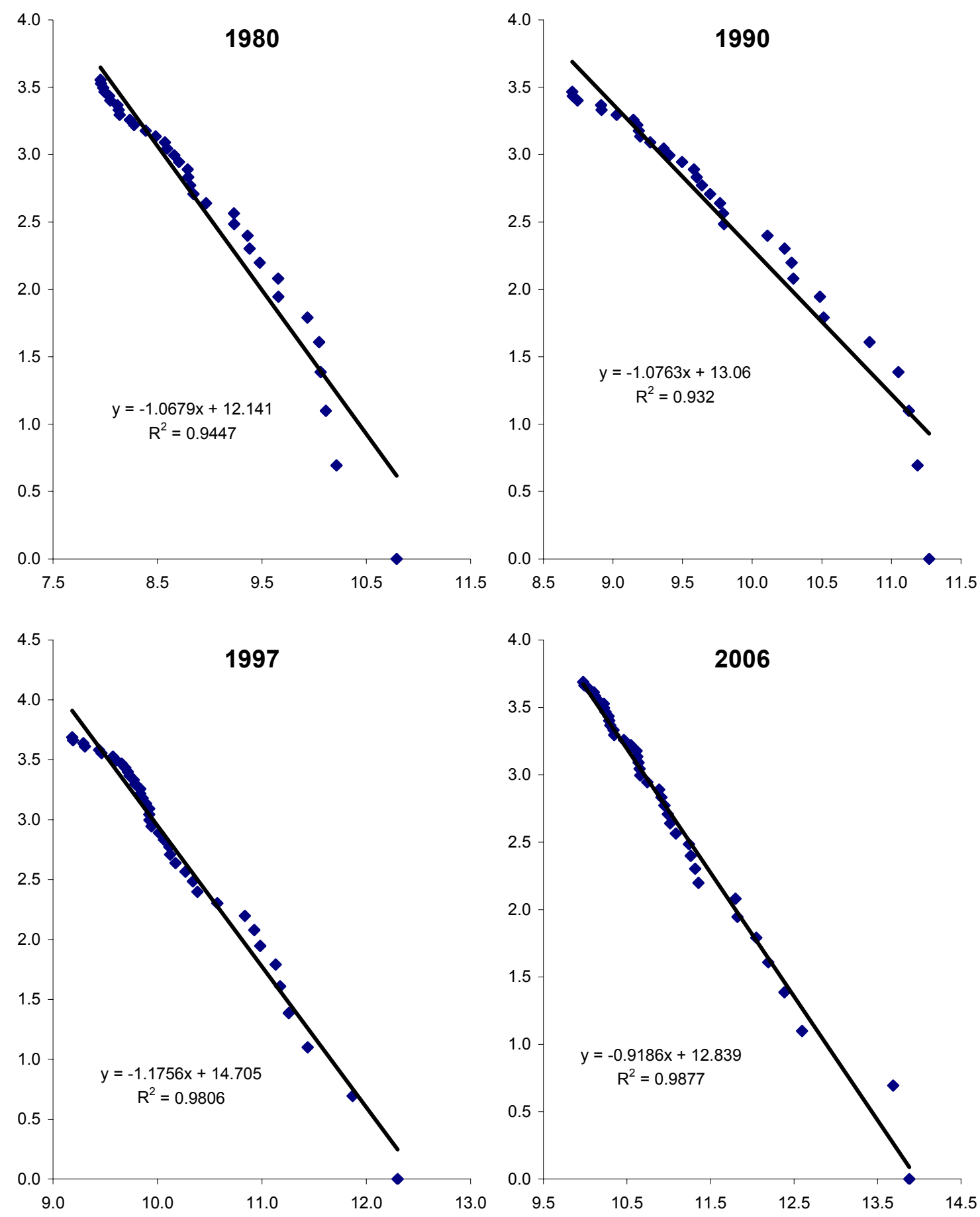

Source: Author's calculations using IMF IFS data on total reserves minus gold. 


\section{Practical Application}

As the evidence of Zipf's law is robust over time, it can be viewed as a useful predictor of the distribution of projected international reserves going forward, for instance the one embedded in the WEO projections. Estimates based on an application of Zipf's law could usefully benchmark projections of reserve accumulation for countries accounting for 90 percent of the world reserve stock. To see if most recent WEO projections of reserves conform to the distribution suggested by Zipf's law I plot Zipf's law for reserves in 2008, 2010, and 2012 in Figure 7. The plots suggest that, over time, projections progressively diverge from distribution implied by Zipf's law. For 90 percent of the total reserves, in 2008, the slope is 0.86 -lower than the estimated slope of 0.92 for 2006. Slopes in 2010 and 2012 are even lower-0.82 in 2010 and 0.79 in 2012. This seems in contradiction to a time-wise robust relation identified in the data.

Figure 7. Zipf's Law for 90 Percent of WEO Projected Reserves-Log Rank on Log Size, 2008-12
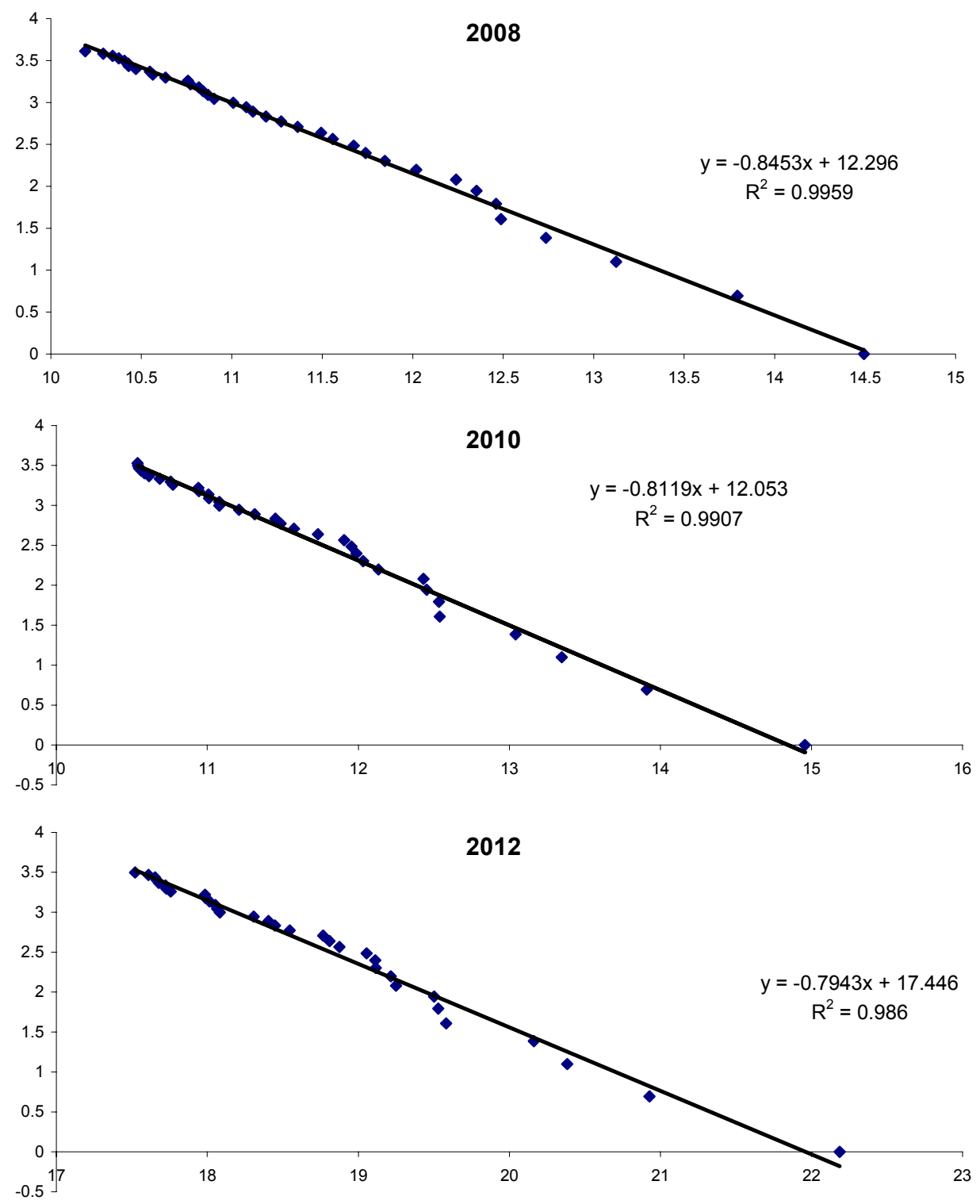

Source: World Economic Outlook (WEO). 


\section{CONCLUSION}

In this short paper I analyzed size distribution of international reserve holdings. I showed that it corresponds reasonably well to Zipf's law and Gibrat's law, both of which apply to size distributions of cities and countries (when ranked by population). This result is presented as an empirical puzzle and informed speculations as to what kind of process might be responsible for this phenomenon are left for future work. 


\section{REFERENCES}

Axtell, Robert L., 2001, “Zipf Distributions o f U.S. Firm Sizes,” Science, Vol. 293, pp. 1818-20.

Ben-Bassat, Avraham, and Daniel Gottlieb, 1992, "On the Effect of Opportunity Cost on International Reserve Holdings," Review of Economics and Statistics, Vol. 74 (May), pp. 329-32.

Bird, Graham, and Ramkishen S. Rajan, 2003, "Too Much of a Good Thing? The Adequacy of International Reserves in the Aftermath of Crises," World Economy, Vol. 26 (June), pp. 873-91.

Beaufort Wijnholds, J.A.H. de, and Arie Kapteyn, 2001, "Reserve Adequacy in Emerging Market Economies,” IMF Working Paper 01/143 (Washington: International Monetary Fund).

Delgado, Ana Paula, and Isabel Maria Godinho, 2004, “The Evolution of City Size Distribution in Portugal: 1864-2001," paper presented at the World Conference of International Regional Science Association, Porto, Portugal, April.

Gabaix, Xavier, 1999, “Zipf's Law for Cities: An Explanation,” The Quarterly Journal of Economics, Vol. 114 (August), pp. 739-67.

Jadresic, Esteban, 2007, "The Cost-Benefit Approach to Reserve Adequacy: the Case of Chile" (mimeo; Central Bank of Chile).

Jeanne, Olivier, 2007, International Reserves in Emerging Market Countries: Too Much of a Good Thing?, Brookings Papers on Economic Activity:1, Brookings Institution, pp. 1-79.

Krugman, Paul, 1996, "Confronting the Mystery of Urban Hierarchy," Journal of the Japanese and International Economies, Vol. 10 (December), pp. 399-418.

Rose, Andrew, 2005, "Cities and Countries," NBER Working Paper No. 11762 (Cambridge, Massachusetts: National Bureau of Economic Research).

Summers, Lawrence H., 2006, “Reflections on Global Account Imbalances and Emerging Markets Reserve Accumulation,” paper presented at L.K. Jha Memorial Lecture, Reserve Bank of India, Mumbai, India, March. Available via the Internet: http://www.president.harvard.edu/speeches/2006/0324 rbi.html.

Sutton, John, 1997, “Gibrat's Legacy,” Journal of Economic Literature, Vol. 35 (March), pp. 40-59.

Zipf, G.K., 1949, "Human Behavior and the Principle of Least Effort" (Cambridge, Massachusetts: Addison-Wesley Press). 